\title{
Attitudes towards anti-smoking legislation and prevalence of tobacco consumption in Spanish primary healthcare personnel
}

\author{
José Manuel Iglesias Sanmartín', Ana Furio Martinez², Lourdes Clemente Jiménez³, Vidal Barchilon Cohen ${ }^{4}$, Cesar Minué- \\ Lorenzo ${ }^{5}$, Sara Cascon Perez-Teijon ${ }^{6}$, Joan Antoni Ribera Osca ${ }^{7}$, Rodrigo Cordoba Garcia ${ }^{8}$, Joan Lozano Fernandez ${ }^{9}$, Miguel \\ Angel Gallardo Domenech ${ }^{10}$, Maria Aranzazu Mendiguren Navascues ${ }^{11}$, Emilio Salguero Chaves ${ }^{12}$, Maria Luz Rodriguez \\ Ibañez ${ }^{13}$, Victoria Gueto Rubio ${ }^{14}$, Susana Morena Rayo ${ }^{15}$, Bruno Marioni Otero ${ }^{16}$, Lucia Gorreto Lopez ${ }^{17}$, Francisco \\ Camarelles Guillem ${ }^{18}$, Fernando Martin Fuente ${ }^{19}$, Diego Beni Ruiz ${ }^{20}$, Alicia Isabel Hernández Rodríguez ${ }^{21}$, Juan De Dios \\ Gonzalez22, Carlos Martin-Cantera ${ }^{23}$
}

\section{ABSTRACT}

INTRODUCTION Our aim was to ascertain how the anti-smoking legislation of 2005/2010 has affected the behavior of primary healthcare center (PHC) personnel (medical and nonmedical) with respect to their attitudes towards tobacco, its consumption and the legislative changes.

METHODS We conducted a multi-center descriptive study of a randomized conglomerate sample of PHC personnel from each Autonomous Community in Spain. The questionnaire covered tobacco consumption, and knowledge/attitudes towards smoking and legislation. The statistical analysis used SPSS software.

RESULTS The sample consisted of 2040 PHC employees (1578 women, $77.4 \%$ ). Never smokers, ex-smokers, and smokers represented $46.7 \%, 37.8 \%$, and $15.5 \%$ of the sample, respectively. Tobacco prevalence amongst physicians and nurses was $12.3 \%$. Following the introduction of the antismoking legislation, a decrease in consumption was observed. Most of the participants considered that tobacco consumption affected health, was an addictive illness, and passive smoking had an impact on the health of non-smokers. Whilst 91.6\% agreed with the current legislation, only $25 \%$ felt that it encouraged cessation.

CONCLUSIONS Spanish primary healthcare professionals have a relatively low prevalence of smoking compared to the general population. It is necessary to implement more legislative measures to improve and maintain this outcome.

\begin{abstract}
AFFILIATION
1 Unidad Especializada de Tabaquismo del Área Sanitaria IV del Principado de Asturias, Spain

2 Centro Salud de Serreria 2, Valencia, Spain

3 Centro Salud La Jota, Zaragoza, Spain

4 Centro Salud Rodriguez Arias-San Fernando, Cádiz, Spain

5 Centro Salud Perales del Río, Getafe-Madrid, Spain

6 Centro Salud Robleda, Salamanca, Spain

7 Centro Salud de Alcásser, Valencia, Spain

8 Centro Salud de Delicias Sur, Zaragoza, Spain

9 Fundación de Atención Primaria de la CAMFiC, Spain

10 Centro Salud de Arnedo, La Rioja, Spain

11 Centro de Salud Parte Vieja San Sebastián, Spain

12 Centro Salud Valdepasillas, Badajoz, Spain

13 Centro Salud de Tolosa, Tolosa, Gipuzkoa, Spain

14 Centro Salud Mendillorri, Pamplona, Navarra, Spain

15 Centro Salud de Hellin, Albacete, Spain

16 Centro Salud Redondela, Redondela, Pontevedra, Spain

17 Centro Salud de Coll d'en Rabassa, Palma de Mallorca, Spain

18 Centro Salud Infanta Mercedes, Madrid, Spain

19 Centro Salud de Vargas, Udesta, Santander, Spain

20 Centro de Salud Alfaro, La Rioja, Spain

21 Centro Salud de Barranco Grande, Tenerife, Spain

22 Subdirección General de Planificación, Cuidados y Cronicidad del Sistema Murciano de Salud, Murcia, Spain

23 Institut Universitari d'Investigació en Atenció Primària Jordi
\end{abstract} Gol (IDIAP Jordi Gol), Spain

\section{CORRESPONDENCE TO}

Carlos Martin-Cantera. Institut Universitari d'Investigació en Atenció Primària Jordi Gol (IDIAP Jordi Gol), Spain.

E-mail: c.martincantera@gmail.com

ORCID ID: https://orcid.org/0000-0003-0656-8126

\section{KEYWORDS}

primary healthcare, epidemiology, smoking behaviours, attitudes health personnel, smoking ban, Spain

Received: 8 November 2018

Revised: 24 January 2019

Accepted: 15 February 2019

\section{INTRODUCTION}

The World Health Organization (WHO) Framework
Convention on Tobacco Control (FCTC) protects 4700 million people, worlwide. Its MPOWER package 
(2008) consists of six measures: monitoring tobacco use and prevention policies; protecting people from tobacco smoke; offering help to quit tobacco use; warning about the dangers of tobacco; enforcing bans on tobacco advertising, promotion and sponsoring; and raising taxes on tobacco ${ }^{1}$.

Primary Healthcare (PHC) personnel play a key role in the prevention and cessation of smoking, and their counselling substantially increases success rates $^{2-4}$. Multi-component $\mathrm{PHC}$ interventions, via telephone support and medication, for individuals wanting to quit, have achieved long-term abstinence with a $10-25 \%$ success rate in comparison with individual counselling ${ }^{5,6}$. Nevertheless, some studies have reported that many PHC personnel do not employ enough resources to encourage patients to stop smoking ${ }^{7,8}$.

In Spain especially, two prohibitions have been introduced in smoke-free legislation (SFL) in 2006, with partial measures (regulations on the sale, supply, consumption and advertising of tobacco products). Subsequently, this was extended with the enactment of an integral SFL (Law 42/2010), which came into force in January 2011. This comprehensive law extended smoking restriction in all hospitality places, regardless of the area of the establishment and, as a result, smoking was banned in all enclosed public places, including bars, restaurants and nightclubs, and in some outdoor public places, such as playgrounds. In European countries where anti-tobacco laws have been evaluated, it has been demonstrated that the impact of such legislation has been positive and has led to a decrease in the prevalence of smoking ${ }^{9}$.

The 2017 WHO Report evaluating legislation enforcement stated that $22(40 \%)$ of the 55 countries with comprehensive smoke-free legislation had elevated compliance rates ${ }^{10}$. The Smoke Free Partnership placed Spain among the countries that best followed the principles of Article 8 of the WHO FCTC $^{11}$.

A meta-analysis carried out by Fichtenberg and Glantz $^{12}$ observed that smoke-free policies were related to a $3-4 \%$ decline in tobacco consumption. Hopkins et al. ${ }^{13}$, in another systematic review, reported a decrease of 2.2 cigarettes/day following legislation. Frazer et al. ${ }^{14}$, however, found that antismoking laws had an inconclusive impact on tobacco prevalence and consumption ${ }^{14}$.

Various Spanish authors have evaluated tobacco consumption amongst PHC personnel and their attitude towards its treatment ${ }^{15-16,18-23}$. For example, in 1997 prevalence was found to be $38.1 \%$ decreasing to $28.7 \%$ by $2008^{18,23}$. A later study in 2015, which included 612 PHC personnel (155 physicians), observed a prevalence of $11.7 \%$ (8.9\% and $11.2 \%$ for physicians and nurses, respectively), although it might not have been possible to accurately distinguish the different groups ${ }^{16}$.

The aim of the present research is to establish how the legislative measures have affected PHC medical and non-medical personnel with respect to their behavior towards tobacco consumption and their opinions concerning smoking and the changes in legislation.

\section{METHODS}

\section{Study design}

A multi-center, transversal, descriptive study was conducted that included PHC medical and nonmedical personnel from the Spanish National Healthcare System. The study was conducted between June 2016 and March 2017.

\section{Sample size}

The sample ( $n=3994$ participants) was made up of 1842 physicians (general practitioners and paediatricians), 1076 nurses (nurses and midwives), and 1076 non-medical personnel. A smoking prevalence of $20 \%$ for the first group, and $30 \%$ for the other two groups was assumed. A $20 \%$ dropout rate was taken into consideration for calculations.

Cluster sampling was carried out in which, initially, by simple random sampling, $5 \%$ of the health centers of each Autonomous Community were selected, which constituted the primary sampling units. Subsequently, as secondary sampling units, all members of the primary care teams of the centers selected in the first phase were selected.

\section{Study survey}

A questionnaire designed by the members of the Approach to Smoking Group (GAT) from the Spanish Family and Community Medical Society was validated during the first phase in a pilot study. The final version was anonymous and online. The voluntary 
collaboration of individuals in charge of the selected PHC was requested by email, and in order to improve participation they were reminded by telephone.

\section{Variables}

\section{Sociodemographic characteristics}

Sociodemographic characteristics included age, gender, PHC location (rural/urban), professional status (general practitioner, paediatrician, nurse, midwife and administrative assistant), years working in the PHC and employment status (permanent, temporary, employed/contracted and other).

\section{Tobacco consumption status}

Consumption status included habitual smoker, occasional smoker, ex-smoker, and never smoked. For smokers, information included: number of cigarettes/day, number of previous attempts to quit, reasons for relapse and at what stage according to the change model of Prochaska and DiClemente ${ }^{17}$. For exsmokers, information included: length of time without smoking.

\section{Attitudes towards smoking}

Attitudes included opinions on the impact of tobacco on health, efficacy of counselling, importance of healthcare personnel as role models, compliance with current regulations, and the wish to really quit (for smokers).

\section{Opinions about anti-smoking legislation}

Attitudes towards the law regarding smoke-free areas, the effect on smokers, smoke-free public areas, and regulation of electronic cigarettes, were obtained. The responses were evaluated on a Likert scale ranging 1 to 5 ( 1 the least and 5 the most favourable; in the statistical analysis $\geq 4$ was considered in agreement).

Whilst not included in the objectives of this publication, the participants were additionally asked, in the case of healthcare personnel, about the smoking interventions carried out in the PHC such as importance, frequency, type of intervention: annotation in medical records, identification of stage of change, no action carried out, brief advice given, intense intervention, frequency of interventions (habitual, related to problems linked to tobacco, etc.). Views with respect to passive smoking were also obtained.
Participants were also asked about prior training to approach smoking, such as whether the participants had received any specific training in tobacco cessation (if so, what kind), and the management of diagnostic and therapeutic measures (medication, psychosocial strategies). A complex variable was produced that considered the management level of diagnostic and treatment measures as two categories (good practice and could be improved).

\section{Ethical considerations}

Prior to the study, participants were informed about the aim of the research and that the questionnaire was voluntary and anonymous. The study was exempt from the Institutional Review Board. No individual identifiers were used at any analytical step.

\section{Data analysis}

Descriptive statistics were used to summarize overall information. A high dropout rate and greater response from participants who were more aware of smoking issues were assumed. Categorical variables were expressed as percentages and continuous ones as means and standard deviation $( \pm \mathrm{SD})$. Comparative analysis was performed with the $\chi^{2}$ test for the former group and Student's t-test and ANOVA for the latter, as applicable. Statistical significance was established by $\mathrm{p}<0.05$. All analyses were performed with the SPSS software program.

\section{RESULTS}

Of the 3994 participants planned, an e-mail interview could be sent to 3965 and 2040 responses (51.45\%) were obtained. The mean age of the respondees was $50.49 \pm 9.59$ years, and the mean number of years worked in the PHC was $17.34 \pm 10.06$. A figure that was higher in medical personnel and lower in midwives $(11.88 \pm 10.27$ years $)$ and non-medical personnel $(14.04 \pm 9.20$ years $)$. More than $75 \%$ were women $(77.4 \%)$ and $73.7 \%$ were employed in urban areas. Most of the personnel had permanent contracts (68.1\%). With respect to tobacco consumption, almost half were never smokers (46.7\%), 37.8\% ex-smokers, and $15.5 \%$ smokers (daily plus occasional smokers). With respect to physicians and nurses, smoking prevalence was $11.8 \%$ and $12.8 \%$, respectively. For non-medical (administrative) personnel, the prevalence was $24.8 \%$. Electronic 
cigarette consumption was minimal (2\%) and so was the number currently not employed (Table 1 ). Among the healthcare personnel who smoked, the mean age at commencement was $18.84 \pm 5.09$ years, with $3 \pm 4.95$ attempts to quit. There was a mean consumption of $10.59 \pm 8.8$ cigarettes/day. With respect to the Prochaska and DiClemente stages of change model ${ }^{17}, 14 \%$ were at the determination (preparation) stage, $25.4 \%$ at contemplation, and $60.6 \%$ precontemplation.

As to the ex-smokers, 2 in 3 had been abstinent for more than 10 years, $17 \%$ between 5 to 10 years, and $11 \%$ between 1 and 5 years. The main reasons for quitting were the effect on one's own health $(86 \%)$, seeking freedom from an addiction $(82.3 \%)$, and concern about the impact on close family members
(64.1\%). Issues such as anti-smoking legislation $(13.9 \%)$ and pressure from relatives and friends (20.6\%) were of less importance. More than half of the healthcare personnel highlighted the importance of representing a role model although significant differences were observed between physicians and nurses, $53.3 \%$ and $40.7 \%(\mathrm{p}=0.002)$, respectively. Nurses $(22.8 \%)$ and non-medical personnel (26.3\%) were influenced more by other healthcare workers than the physicians $(\mathrm{p}=0.021)$.

Cessation was quite/very easy for $41.6 \%$ of the ex-smoker participants and quite/very difficult for $34.3 \%$. In addition, 4 in 5 of the healthcare personnel quit tobacco without any kind of help whilst 8.7\% received professional care or other kind of support (e.g. books, hypnosis).

Table 1. Sociodemographic characteristics and smoking prevalence among the PIC personnel who answered the questionnaire

\begin{tabular}{|c|c|c|c|c|c|c|c|}
\hline Variables & $\begin{array}{c}\text { Total }{ }^{*} \\
\text { N (\% total) }\end{array}$ & $\begin{array}{l}\text { Physician } \\
\text { N (\% total) }\end{array}$ & $\begin{array}{l}\text { Nurse } \\
\text { N }(\% \text { tolal })\end{array}$ & $\begin{array}{l}\text { Pediatrician } \\
\text { N (\% total) }\end{array}$ & $\begin{array}{l}\text { Vidwile } \\
\text { N (\% total) }\end{array}$ & $\begin{array}{c}\text { Other } \\
\text { N (\% total })\end{array}$ & $p$ \\
\hline Participants* & $2040(100)$ & $736(38.2)$ & $698(36.2)$ & $56(2.9)$ & $24(1.2)$ & $413(21.4)$ & \\
\hline Age $\left({ }^{*}\right.$ Mean $\left.\pm S D\right)$ & $50.49 \pm 9.59$ & $51.22 \pm 9.59$ & $49.75 \pm 9.84$ & $51.09 \pm 11.55$ & $49.58 \pm 10.76$ & $49.95 \pm 8.48$ & 0.038 \\
\hline \multicolumn{8}{|l|}{ Gender } \\
\hline Male & $462(22.6)$ & $251(34.1)$ & $106(15.2)$ & $9(16.1)$ & $1(4.2)$ & $78(18.9)$ & 0.000 \\
\hline Female & $1578(77.4)$ & $485(65.9)$ & $592(84.8)$ & 47 (83.9) & 23 (95.8) & $335(81.1)$ & \\
\hline \multicolumn{8}{|l|}{ Healthcare Center } \\
\hline Urban & $1504(73.7)$ & $525(71.3)$ & $506(72.5)$ & $42(75)$ & $21(87.5)$ & $326(78.9)$ & 0.073 \\
\hline Rural & $536(26.3)$ & $211(28.7)$ & $192(27.5)$ & $14(25)$ & $3(22.5)$ & $87(21.1)$ & \\
\hline \multicolumn{8}{|l|}{ Laboral Status } \\
\hline Permanent & $1389(68.1)$ & $527(71.6)$ & $471(67.5)$ & $43(76.8)$ & $14(58.3)$ & $252(61.1)$ & 0.006 \\
\hline Temporary & $344(16.9)$ & $102(13.9)$ & $126(18.1)$ & $9(16.1)$ & $6(25)$ & $84(20.3)$ & \\
\hline Employed/Contracted & $228(11.2)$ & $72(9.7)$ & $83(11.8)$ & $4(7.1)$ & $4(16.7)$ & $57(13.8)$ & \\
\hline Other & $79(3.8)$ & $35(4.8)$ & $18(2.6)$ & - & - & $20(4.8)$ & \\
\hline \multicolumn{8}{|l|}{ Smoking status $(N=2024)$} \\
\hline Non-smoker & $1710(84.5)$ & $649(88.2)$ & 609 (87.2) & $54(96.4)$ & $18(75.0)$ & $310(75.1)$ & \\
\hline Never smoked & $945(46.7)$ & $383(52.0)$ & $315(45.1)$ & $45(80.4)$ & $10(41.7)$ & $168(40.7)$ & \\
\hline Ex-smoker & 765 (37.8) & $266(36.1)$ & $294(42.1)$ & $9(16.1)$ & 8 (33.3) & $142(34.4)$ & 0.000 \\
\hline Smoker & $314(15.5)$ & $87(11.8)$ & $89(12.8)$ & $2(3.6)$ & $6(25.0)$ & $103(24.9)$ & \\
\hline Daily & $231(11.4)$ & $58(7.9)$ & $67(9.6)$ & $2(3.6)$ & $4(16.7)$ & $82(19.9)$ & \\
\hline Occasionally & $83(4.1)$ & $29(3.9)$ & $22(3.2)$ & - & $2(8.3)$ & $21(5.1)$ & \\
\hline \multicolumn{8}{|l|}{ Electronic cigarette status $(\mathrm{N}=2024)$} \\
\hline Non-user & 2008 (99.2) & 733 (99.6) & $692(99.2)$ & $56(100)$ & $24(100)$ & $408(98.8)$ & \\
\hline Never & 1968 (97.2) & 721 (98.0) & 679 (97.3) & $56(100)$ & $24(100)$ & $391(95.9)$ & \\
\hline Ex-user & $40(2.0)$ & $12(1.6)$ & $13(1.9)$ & - & - & $17(2.9)$ & 0.000 \\
\hline User & $16(0.8)$ & $3(0.4)$ & $6(0.8)$ & - & - & $5(1.2)$ & \\
\hline Daily & $6(0.3)$ & $1(0.1)$ & $3(0.4)$ & - & - & $1(0.2)$ & \\
\hline Occasionally & $10(0.5)$ & $2(0.3)$ & $3(0.4)$ & - & - & $4(1.0)$ & \\
\hline
\end{tabular}

*In total number is included 113 missing dates from profession. 


\section{Opinion about tobacco}

Whilst no significant differences in opinion about tobacco were observed between men and women, location of the PHC (urban/rural), and professional status, there was, however, a difference between those who had been employed for more or fewer than 10 years. The former considered tobacco a chronic illness $(p=0.003)$ that increased the risk of ischemic cardiopathy $(\mathrm{p}=0.036)$. Moreover, they believed that healthcare personnel represented a role model, their advice was effective in quitting tobacco, and that electronic cigarettes were harmful to one's health ( $p=0.000$ for all points). Regarding PHC medical personnel and their opinion about anti-smoking legislation changes, there were significant differences with respect to the efficacy of counselling $(\mathrm{p}<0.001)$, and whether or not electronic cigarettes were harmful $(\mathrm{p}=0.002)$, again in favour of those employed for more than 10 years (Table 2).

Table 2. Opinions about tobacco according to profession and smoking status among primary healthcare personnel

\begin{tabular}{|c|c|c|c|c|c|c|c|c|c|}
\hline \multirow[t]{2}{*}{ OPINIONS } & \multicolumn{4}{|c|}{ PROFESSION } & \multicolumn{5}{|c|}{ SYOKING STATUS } \\
\hline & $\begin{array}{c}\text { Total } \\
\mathbf{N} \\
(\%)\end{array}$ & $\begin{array}{c}\text { NII } \\
\text { Physician * } \\
\text { N } \\
(\%)\end{array}$ & $\begin{array}{c}\text { NII } \\
\text { Nurse ** } \\
\mathbf{N} \\
(\%)\end{array}$ & $\begin{array}{c}\text { Von- } \\
\text { medical } \\
\mathbf{N} \\
(\%)\end{array}$ & p & $\begin{array}{c}\text { Total } \\
\text { N } \\
(\%)\end{array}$ & $\begin{array}{c}\text { Non } \\
\text { smoker } \\
\text { N } \\
(\%)\end{array}$ & $\begin{array}{c}\text { Smoker } \\
\qquad \begin{array}{c}\mathbf{N} \\
(\%)\end{array}\end{array}$ & $p$ \\
\hline $\begin{array}{l}\text { Tobacco has harmful effects on } \\
\text { smokers' health }\end{array}$ & $\begin{array}{r}1923 \\
(99.8)\end{array}$ & $\begin{array}{c}791 \\
(99.9)\end{array}$ & $\begin{array}{c}721 \\
(99.9)\end{array}$ & $\begin{array}{c}411 \\
(99.5)\end{array}$ & 0.378 & $\begin{array}{l}2019 \\
(99.6)\end{array}$ & $\begin{array}{l}1707 \\
(99.8)\end{array}$ & $\begin{array}{c}312 \\
(99.4)\end{array}$ & 0.130 \\
\hline $\begin{array}{l}\text { Exposure to tobacco smoke has an } \\
\text { impact on non-smokers }\end{array}$ & $\begin{array}{r}1910 \\
(99.0)\end{array}$ & $\begin{array}{c}786 \\
(99.2)\end{array}$ & $\begin{array}{c}719 \\
(99.6)\end{array}$ & $\begin{array}{c}405 \\
(98.1)\end{array}$ & 0.027 & $\begin{array}{l}2005 \\
(98.4)\end{array}$ & $\begin{array}{l}1699 \\
(99.4)\end{array}$ & $\begin{array}{c}306 \\
(97.5)\end{array}$ & 0.001 \\
\hline Smoking is a chronic illness & $\begin{array}{r}1678 \\
(85.5)\end{array}$ & $\begin{array}{c}749 \\
(94.6)\end{array}$ & $\begin{array}{c}609 \\
(84.3)\end{array}$ & $\begin{array}{c}320 \\
(77.5)\end{array}$ & 0.000 & $\begin{array}{r}1759 \\
(86.4)\end{array}$ & $\begin{array}{r}1490 \\
(87.1)\end{array}$ & $\begin{array}{c}269 \\
(85.7)\end{array}$ & 0.479 \\
\hline $\begin{array}{l}\text { Healthcare workers are a role } \\
\text { model for patients in some aspects }\end{array}$ & $\begin{array}{l}1662 \\
(84.7)\end{array}$ & $\begin{array}{c}712 \\
(89.9)\end{array}$ & $\begin{array}{c}634 \\
(87.8)\end{array}$ & $\begin{array}{c}316 \\
(76.5)\end{array}$ & 0.000 & $\begin{array}{l}1747 \\
(82.2)\end{array}$ & $\begin{array}{l}1507 \\
(88.1)\end{array}$ & $\begin{array}{c}240 \\
(76.4)\end{array}$ & 0.000 \\
\hline $\begin{array}{l}\text { Passive smoking increases the risk of } \\
\text { ischemic cardiopathy in non-smokers }\end{array}$ & $\begin{array}{r}1630 \\
(82.2)\end{array}$ & $\begin{array}{c}704 \\
(88.9)\end{array}$ & $\begin{array}{c}637 \\
(87.8)\end{array}$ & $\begin{array}{l}289 \\
(70)\end{array}$ & 0.000 & $\begin{array}{l}1706 \\
(79.4)\end{array}$ & $\begin{array}{r}1479 \\
(86.5)\end{array}$ & $\begin{array}{c}227 \\
(72.3)\end{array}$ & 0.000 \\
\hline Smoking is an addictive illness & $\begin{array}{r}1889 \\
(97.8)\end{array}$ & $\begin{array}{c}781 \\
(98.6)\end{array}$ & $\begin{array}{c}710 \\
(98.3)\end{array}$ & $\begin{array}{c}398 \\
(96.4)\end{array}$ & 0.022 & $\begin{array}{r}1982 \\
(97.6)\end{array}$ & $\begin{array}{l}1677 \\
(98.1)\end{array}$ & $\begin{array}{c}305 \\
(97.1)\end{array}$ & 0.285 \\
\hline $\begin{array}{l}\text { Medical counselling is effective } \\
\text { for smoking cessation }\end{array}$ & $\begin{array}{r}1550 \\
(77.3)\end{array}$ & $\begin{array}{c}718 \\
(90.7)\end{array}$ & $\begin{array}{c}581 \\
(80.5)\end{array}$ & $\begin{array}{c}251 \\
(60.8)\end{array}$ & 0.000 & $\begin{array}{l}1632 \\
(74.2)\end{array}$ & $\begin{array}{r}1428 \\
(83.5)\end{array}$ & $\begin{array}{l}204 \\
(65)\end{array}$ & 0.000 \\
\hline $\begin{array}{l}\text { Electronic cigarettes are harmful } \\
\text { for health }\end{array}$ & $\begin{array}{r}1282 \\
(63.6)\end{array}$ & $\begin{array}{c}576 \\
(72.7)\end{array}$ & $\begin{array}{c}508 \\
(70.4)\end{array}$ & $\begin{array}{c}198 \\
(47.9)\end{array}$ & 0.000 & $\begin{array}{l}1344 \\
(61.2)\end{array}$ & $\begin{array}{r}1175 \\
(68.7)\end{array}$ & $\begin{array}{c}169 \\
(53.8)\end{array}$ & 0.000 \\
\hline
\end{tabular}

*All Physician: In this table Physician plus Pediatrician. ${ }^{*}$ All Nurse: In this table Nurse plus Midwife.

\section{Opinion about anti-smoking legislation}

Concerning the current legislation, $92 \%$ of the participants agreed with it. Nevertheless, $25 \%$ were of the view that it did not encourage individuals to quit. Almost 100\% considered that healthcare centers and closed public areas should be smoke-free, although almost 1 in 5 thought that electronic cigarettes need not be prohibited in closed areas ( 1 in 4 in the case of non-medical personnel).

We did not observe differences in opinion about anti-smoking legislation, whether healthcare centers and closed public spaces should be smoke-free, and prohibition of electronic cigarettes in closed public areas with respect to gender, $\mathrm{PHC}$ location, professional status, and years of PHC employment (Table 3). 
Table 3. Opinions about anti-smoking legislation according to profession and smoking status among primary healthcare personnel

\begin{tabular}{|c|c|c|c|c|c|c|c|c|c|}
\hline \multirow[t]{2}{*}{ OPINIONS } & \multicolumn{5}{|c|}{ PROFESSION } & \multicolumn{4}{|c|}{ SVOKIVG STATUS } \\
\hline & $\begin{array}{c}\text { Total } \\
\mathbf{N} \\
(\%)\end{array}$ & $\begin{array}{c}\text { AII } \\
\text { Physician } \\
\text { N } \\
(\%)\end{array}$ & $\begin{array}{c}\text { All } \\
\text { Nurse ** } \\
\mathbf{N} \\
(\%)\end{array}$ & $\begin{array}{c}\text { Yon- } \\
\text { medical } \\
\mathbf{N} \\
(\%)\end{array}$ & $p$ & $\begin{array}{c}\text { Total } \\
\mathbf{N} \\
(\%)\end{array}$ & $\begin{array}{c}\text { Non- } \\
\text { smoker } \\
\text { N } \\
(\%)\end{array}$ & $\begin{array}{c}\text { Smoker } \\
\text { N } \\
(\%)\end{array}$ & p \\
\hline $\begin{array}{l}\text { I totally agree with the current } \\
\text { anti-smoking legislation }\end{array}$ & $\begin{array}{c}1777 \\
(91.6)\end{array}$ & $\begin{array}{l}736 \\
(92.9)\end{array}$ & $\begin{array}{c}676 \\
(93.6)\end{array}$ & $\begin{array}{c}365 \\
(88.4)\end{array}$ & 0.005 & $\begin{array}{c}1861 \\
(87.0)\end{array}$ & $\begin{array}{l}1610 \\
(94.2)\end{array}$ & $\begin{array}{c}251 \\
(79.9)\end{array}$ & 0.000 \\
\hline $\begin{array}{l}\text { Healthcare centers should be } \\
\text { smoke-free }\end{array}$ & $\begin{array}{r}1919 \\
(99.5)\end{array}$ & $\begin{array}{c}789 \\
(99.6)\end{array}$ & $\begin{array}{c}720 \\
(99.7)\end{array}$ & $\begin{array}{c}410 \\
(99.3)\end{array}$ & 0.515 & $\begin{array}{l}2013 \\
(99.1)\end{array}$ & $\begin{array}{c}1703 \\
(99.6)\end{array}$ & $\begin{array}{c}310 \\
(98.7)\end{array}$ & 0.076 \\
\hline $\begin{array}{l}\text { Anti-smoking legislation helps } \\
\text { smokers to consider quitting }\end{array}$ & $\begin{array}{r}1445 \\
(72.7)\end{array}$ & $\begin{array}{c}637 \\
(80.4)\end{array}$ & $\begin{array}{c}558 \\
(77.3)\end{array}$ & $\begin{array}{c}250 \\
(60.5)\end{array}$ & 0.000 & $\begin{array}{l}1520 \\
(81.7)\end{array}$ & $\begin{array}{c}1331 \\
(77.8)\end{array}$ & $\begin{array}{c}189 \\
(85.7)\end{array}$ & 0.000 \\
\hline $\begin{array}{l}\text { Closed public spaces should be } \\
\text { smoke free }\end{array}$ & $\begin{array}{r}1898 \\
(98.8)\end{array}$ & $\begin{array}{c}778 \\
(99.5)\end{array}$ & $\begin{array}{c}717 \\
(99.3)\end{array}$ & $\begin{array}{c}403 \\
(97.6)\end{array}$ & 0.004 & $\begin{array}{l}2000 \\
(97.6)\end{array}$ & $\begin{array}{r}1699 \\
(99.4)\end{array}$ & $\begin{array}{c}301 \\
(95.9)\end{array}$ & 0.000 \\
\hline $\begin{array}{l}\text { Electronic cigarettes should be } \\
\text { banned in closed public spaces }\end{array}$ & $\begin{array}{r}1578 \\
(80.6)\end{array}$ & $\begin{array}{c}666 \\
(84.1)\end{array}$ & $\begin{array}{c}608 \\
(84.2)\end{array}$ & $\begin{array}{c}304 \\
(73.6)\end{array}$ & 0.000 & $\begin{array}{r}1659 \\
(80.1)\end{array}$ & $\begin{array}{l}1468 \\
(99.4)\end{array}$ & $\begin{array}{c}191 \\
(60.8)\end{array}$ & 0.000 \\
\hline
\end{tabular}

*All Physician: Physicians and Pediatricians. ${ }^{* *}$ All Nurse: Nurses and Midwives.

\section{DISCUSSION}

We presented the results of a national survey carried out in 2017 with a total of 2040 PHC personnel: $15.5 \%$ were smokers, with a greater prevalence among administrative staff ( $24.9 \%)$, and more nurses consumed tobacco $(12.8 \%)$ than physicians $(11.8 \%)$ or paediatricians $(3.6 \%)$. The use of electronic cigarettes was very low $(0.8 \%)$. Our findings show minor differences regarding opinion about tobacco and legislation in smoke-free areas between smoking and non-smoking personnel.

\section{Comparison of consumption data in Spain}

Research carried out prior to the first legislation of 2006 shows that healthcare personnel smoked far more than we found in our present study. In 1997, Gordo et al. ${ }^{23}$ reported that $38.1 \%$ were smokers although data were only obtained from one region (Guadalajara). In 2002, Casas et al. ${ }^{22}$ found $26.5 \%$ in Barcelona, however, the study included other medical specialists and differences in consumption were found among administrative staff (35.9\%), nurses (31.2\%), and physicians (15.8\%). A follow-up study by Fernández Ruiz and Sanchez ${ }^{21}$ from 1998 to 2001 of 1235 female medical personnel representing 31.65\% (1998) and 39.1\% (2001) of the personnel in their PHC, reported a smoking prevalence of $43.1 \%$ in 1998 and $43 \%$ in 2001. In both years, tobacco consumption was more frequent among the nurses $(47.6 \%$ and $47 \%$, respectively) than the physicians (34.7\% and $37 \%$, respectively), and among those employed in hospital care $(46.6 \%$ and $46.7 \%$, respectively) compared to PHC (35.3\% and $37.3 \%$, respectively). The 2005 study by Cerrada et al. ${ }^{20}$ with healthcare personnel in Madrid observed a 21.6\% prevalence of tobacco consumption.

Following the initial 2006 legislation, Tenas et al. ${ }^{19}$, in 2008 , reported that $28.7 \%$ of PHC personnel in the region of Murcia declared themselves smokers.

In 2015, Jiménez-Ruiz et al. ${ }^{16}$ published consumption data from a sample of 612 healthcare personnel (155 PHC physicians). They reported a prevalence of $11.7 \%$ with differences between physicians $(8.99 \%)$ and nurses $(11.2 \%)$.

In conclusion, our findings show a reduction in the prevalence of smokers among PHC medical personnel. There was a $13 \%$ decrease compared to 2006 and even greater when compared with 1998.

\section{Comparison with other countries}

Studies by Ravara et al. ${ }^{24,25}$ with 605 physicians (196 family doctors) in northern Mediterranean countries and Portugal observed that $20.4 \%$ of the smokers were family doctors. In Italy, Nobile et al. ${ }^{26}$ reported that there were $13.4 \%$ smokers from a sample of 722 PHC physicians. Sonmez et al. ${ }^{27}$, in Turkey, with a sample of 1182 physicians and 1063 nurses, found a smoking prevalence of $34.4 \%$ and $30.7 \%$, 
respectively. In Croatia, Juranic et al. ${ }^{28}$ reported that $35.1 \%$ of healthcare personnel were habitual smokers whilst Azuri and Nashef ${ }^{29}$, in Israel, with a sample of 302 physicians, observed a prevalence of $13.5 \%$. Stamatopoulou et al. ${ }^{30}$, in a study undertaken in 40 health centers in rural mainland and island Greece, reported that $32 \%$ of the nurse respondents were smokers. Data from a study carried out by Huddlestone et al. ${ }^{31}$ in the UK with a sample of 171 PHC personnel revealed that $11 \%$ consumed tobacco.

A possible explanation for the differences found between these countries may be a different application of the laws, if we take as reference the Smoke Free Partnership and the data of The Tobacco Control Scale 2016 (Table 4). In conclusion, our data show a low level of consumption, compared to some of the studies in the Mediterranean area, which have been carried out in different years but all in primary healthcare and similar to the study in England.

\section{Comparison with other healthcare personnel in Spain}

In a four-year follow-up (2001, 2004, 2008, and 2011) carried out with hospital employees in Spain, Reyes et al. ${ }^{18}$ observed an increase in smoking prevalence from $30.00 \%$ in 2001 to $36.21 \%$ in 2008 followed by a decrease to $29.42 \%$ in 2011 . In the group of physicians, it decreased progressively from $25.97 \%$ in 2001 to $8.88 \%$ in $2011(\mathrm{p}=0.007)$ whilst in that of nurses it went from $35.15 \%$ in 2001 to $25.61 \%$ in 2011 ( $\mathrm{p}=0.007$ ). With respect to administrative staff, the highest figure for this group was $43.93 \%$ in 2008 , decreasing to $35.71 \%$ in 2011 . Perez-Rios et al. ${ }^{9}$ also analyzed data before and after the 2010 legislation and found a non-significant reduction of $23.4 \%$ in 2006 and $20.7 \%$ in 2011 . Our data partially coincide with the reduction found in other health professionals in Spain. A possible explanation can be that primary healthcare professionals attend to a higher number of patients with this problem and that several initiatives have been developed in primary healthcare to reduce tobacco consumption such as the 'smoke-free week' in primary care.

\section{Comparison with other data from the general population}

According to data from the 2017 Eurobarometer ${ }^{34}$, $24 \%$ of the population in the European Union (EU) consider themselves daily smokers. A figure that rises in some southern European countries (36\% in Bulgaria, $35 \%$ in Greece, and 33\% in Croatia) and France (33\%). In contrast, most of the countries in northern Europe,

Table 4. Ranking according to The Tobacco Control Scale (TTS) $2016^{*}$ in Europe and MPOWER framework in a selection of WHO Europe Region countries**

\begin{tabular}{|c|c|c|c|c|c|c|c|c|}
\hline \multirow[t]{2}{*}{$\begin{array}{l}\text { Author and } \\
\text { Coumtry }\end{array}$} & \multirow[t]{2}{*}{$\begin{array}{l}\text { Ranking } \\
\text { TTS }^{\circ}\end{array}$} & \multirow[t]{2}{*}{$\begin{array}{c}\text { Punctuation } \\
\text { TTS * }\end{array}$} & \multirow{2}{*}{$\begin{array}{l}\text { Smoke free } \\
\text { legislation } \\
. .\end{array}$} & \multirow{2}{*}{$\begin{array}{l}\text { Number of } \\
\text { articles fully } \\
\text { implemented }\end{array}$} & \multirow{2}{*}{$\begin{array}{c}\text { Price } \\
\text { and tax } \\
\text { measures }\end{array}$} & \multirow{2}{*}{$\begin{array}{l}\text { Tobacco } \\
\text { dependency } \\
\text { and } \\
\text { cessation" }\end{array}$} & \multicolumn{2}{|c|}{$\begin{array}{l}\text { Tobacco use in } \\
\text { Primary Care }\end{array}$} \\
\hline & & & & & & & Doctors & Vurses \\
\hline $\begin{array}{l}\text { Huddlestone et al. }{ }^{31} \\
\text { UK (2015) }\end{array}$ & 1 & 81 & Yes & 4 & Yes & Partly & $11 \%$ & - \\
\hline $\begin{array}{l}\text { Spain }^{30} \\
(2018)\end{array}$ & 8 & 55 & Yes & 7 & No & Partly & $11.8 \%$ & $12.8 \%$ \\
\hline $\begin{array}{l}\text { Sonmez et al. }{ }^{27} \\
\text { Turkey (2015) }\end{array}$ & 9 & 53 & Partly & 2 & Yes & Partly & $34.4 \%$ & $30.7 \%$ \\
\hline $\begin{array}{l}\text { Nobile et al. } .^{26} \\
\text { Italy (2012) }\end{array}$ & 13 & 51 & Yes & 2 & Partly & Partly & $13.4 \%$ & - \\
\hline $\begin{array}{l}\text { Ravara et al. }{ }^{25} \\
\text { Portugal (2009) }\end{array}$ & 15 & 50 & Yes & 4 & Partly & Yes & $20.4 \%$ & - \\
\hline $\begin{array}{l}\text { Juranic et al. } 28 \\
\text { Croatia (2017) }\end{array}$ & 23 & 45 & Yes & 9 & Yes & Yes & $35.1 \%$ & - \\
\hline $\begin{array}{l}\text { Stamatopoulou et al. }{ }^{30} \\
\text { Greece (2014) }\end{array}$ & 31 & 40 & Yes & 1 & No & No & - & $22 \%$ \\
\hline
\end{tabular}

* Glahn et al. ${ }^{32}$ (2018), ${ }^{* *}$ Joossens \&t Raw ${ }^{33}$ (2017). 
particularly Sweden (5\%) but also the UK, Holland and Denmark (all 16\%), Belgium (17\%), and Finland (28\%) report a lower prevalence. Whilst at 26\% Spain is little higher than the $\mathrm{EU}$ mean ${ }^{29}$, our findings show that PHC personnel (15.5\%) are more than $10 \%$ below the European value. Moreover, if we take into consideration prevalence for physicians $(11.8 \%)$ and nurses $(12.8 \%)$, the difference is even more marked.

According to the same 2017 survey, electronic cigarette use stands at $2 \%$ throughout the $\mathrm{EU}^{31}$ and $1 \%$ in Spain. We found a slightly lower value of $0.8 \%$.

\section{Comments with respect to opinions about tobacco and anti-smoking legislation}

In 1997, Alonso et al. ${ }^{23}$ reported that $91.3 \%$ of nonsmoking healthcare personnel, compared to $48.2 \%$ of the smokers, were in favor of a normative that would prohibit smoking in the PHC. In 2002, Casas et al. ${ }^{22}$ found that $68.1 \%$ of the healthcare personnel considered that the non-smoking signs in the centers were inadequate, $72.8 \%$ did not respect the legislation, $77.2 \%$ thought there should be reserved areas for smokers, and $61.2 \%$ objected to other people smoking in the center. Fernández Ruiz and Sanchez ${ }^{21}$ observed similar opinions regarding legislation. Such findings contrast with those of our study, where 99.6\% thought there should be smoke-free areas and $92.2 \%$ agreed with the normative, although there were some differences between non-smokers $(94.2 \%)$ and smokers $(79.9 \%)$. We are thus led to conclude that the 2010 legislation has had a very positive effect on the opinions and behavior of PHC healthcare personnel towards tobacco consumption and associated legislation. It has had an influence on their acceptance of the normative and resulted in a decrease in tobacco consumption.

\section{Limitations and strengths}

Our study has some limitations. Due to the possible self-selection of the participants and the questionnaire that was based on self-reporting, bias may be implied. There could have been an underestimation of the real rate of smoking prevalence and misrepresentation of attitudes towards smoking and legislation. We are aware that such questionnaires are open to respondees' prejudices, particularly regarding a theme such as smoking behavior.

Participation was voluntary and some smokers may have avoided answering the questionnaire or changed their response. Whilst our results are not completely representative of Spanish healthcare personnel, they do reflect those who habitually work in PHC $^{35}$. Moreover, our sample is the largest to date and has included the whole of Spain. Some sociodemographic data that could have been of interest, such as marital status and socioeconomic level, have, however, not been included.

\section{CONCLUSIONS}

For several years now, the prevalence of smokers among PHC medical personnel in Spain has been steadily decreasing possibly due to, among other reasons, legislative initiatives. Opinions and attitudes regarding smoking and smoke-free regulated areas have improved among PHC personnel. There have been no major changes in primary healthcare since 2005. In Spain, activities have been carried out, such as the 'smoke-free week', in which only primary care professionals participate, with activities that encourage the population to stop smoking. There have been no changes in the financing of treatments to stop smoking, or in the attention to the smoker by the health system. At the public level, the laws of 2005 and 2010 have been widely discussed in the daily press and possibly this has influenced the behavior of health professionals in general, especially those in primary healthcare.

In Spain, the National Committee for the Prevention of Smoking (CNPT) has proposed several actions to promote the denormalization of tobacco such as: implementation of generic packaging, an increase in advertising campaigns to prevent consumption, price equalization of different tobacco products, equivalent legislation for electronic cigarettes, consideration of new smoke-free areas, especially in places where minors can be exposed (home, private vehicle), and the expansion of help for cessation of consumption (financing of pharmacological treatment in certain groups and promoting the training of health professionals in effective interventions to stop smoking). Implementing these measures is expected to give better results.

\section{REFERENCES}

1. World Health Organization. MPOWER: Six Policies to Reverse the Tobacco Epidemic. World Health 
Organization; 2008.

2. Cabezas C, Advani M, Puente D, Rodriguez T, MartinCantera C, ISTAPS Study Group. Effectiveness of a Stepped Primary Care Smoking Cessation Intervention: Cluster Randomized Clinical Trial (ISTAPS study). Addiction. 2011;106(9):1696-1706. doi:10.1111/j.1360-0443.2011.03491.x

3. Jepson RG, Harris FM, Platt S, Tannahill C. The effectiveness of interventions to change six health behaviours: a review of reviews. BMC Public Health. 2010;10:538. doi:10.1186/1471-2458-10-538

4. Stead LF, Buitrago D, Preciado N, Sanchez G, HartmannBoyce J, Lancaster T. Physician advice for smoking cessation. Cochrane Database Syst Rev. 2013;(5):CD000165. doi:10.1002/14651858.CD000165.pub4

5. Stead LF, Koilpillai P, Lancaster T. Additional behavioural support as an adjunct to pharmacotherapy for smoking cessation. Cochrane Database Syst Rev. 2015;(10):CD009670. doi:10.1002/14651858.CD009670.pub3

6. Martin-Cantera C, Puigdomenech E, Ballve JL, Arias OL, Clemente L, Casas R, et al. Effectiveness of multicomponent interventions in primary healthcare settings to promote continuous smoking cessation in adults: a systematic review. BMJ Open. 2015;5(10):e008807. doi:10.1136/bmjopen-2015-008807

7. Cakir B, Tas A, Sanver TM, Aslan D. Doctor's enquiry: an opportunity for promoting smoking cessationfindings from Global Adult Tobacco Surveys in Europe. Eur J Public Health. 2017;27(5):921-925. doi:10.1093/eurpub/ckx094

8. Tong EK, Strouse R, Hall J, Kovac M, Schroeder SA. National survey of U.S. health professionals' smoking prevalence, cessation practices, and beliefs. Nicotine Tob Res. 2010;12(7):724-733. doi:10.1093/ntr/ntq071

9. Perez-Rios M, Fernandez E, Schiaffino A, Nebot M, Lopez MJ. Changes in the Prevalence of Tobacco Consumption and the Profile of Spanish Smokers after a Comprehensive Smoke-Free Policy. PLoS One. 2015;10(6):e0128305. doi:10.1371/journal.pone.0128305.

10. World Health Organization. WHO report on the global tobacco epidemic, 2017: monitoring tobacco use and prevention policies; 2017.

11. Smoke Free Partnership. 2016 Annual Report. Smoke Free Partnership: a world without tobacco 2016. https:// smokefreepartnership eu/about-us/annual-reports/2016annual-report 2016. Accessed November 8, 2018.

12. Fichtenberg CM, Glantz SA. Effect of smoke-free workplaces on smoking behaviour: systematic review. BMJ. 2002;325(7357):188. PMID:12142305

13. Hopkins DP, Razi S, Leeks KD, Priya KG, Chattopadhyay SK, Soler RE. Smokefree policies to reduce tobacco use. A systematic review. Am J Prev Med. 2010;38(2 Suppl):S275-289. doi:10.1016/j.amepre.2009.10.029

14. Frazer K, Callinan JE, McHugh J, van BS, Clarke A, Doherty K, et al. Legislative smoking bans for reducing harms from secondhand smoke exposure, smoking prevalence and tobacco consumption. Cochrane Database Syst Rev. 2016;2:CD005992. doi:10.1002/14651858.CD005992.pub3

15. Martinez C, Martinez-Sanchez JM, Anton L, et al. Prevalencia de consumo de tabaco en trabajadores hospitalarios: metaanálisis en 45 hospitales catalanes (Smoking prevalence in hospital workers: meta-analysis in 45 Catalan hospitals). Gac Sanit. 2016;30(1):55-58. doi:10.1016/j.gaceta.2015.08.006

16. Jimenez-Ruiz CA, Riesco Miranda JA, Ramos PA, et al. Prevalence of and Attitudes towards Smoking among Spanish Health Professionals. Respiration. 2015;90(6):474-480. doi:10.1159/000441306

17. Prochaska JO, Redding CA, Evers KE. The Transtheoretical model and stages of change. In: Glanz K, Rimer BK, Viswanath K. Health behavior and health education. Theory, research, and practice. 4th ed. San Francisco, CA: John Wiley \& Sons, Inc; 2008:97-122.

18) Reyes Uruena JM, Buron PA, Sala SM, Serra PC, Diaconu A, Macia GF. Evolución del consumo de tabaco en trabajadores de un hospital de Cataluña (Temporal evolution of tobacco consumption among health care workers in a Catalonian hospital, Spain). Rev Esp Salud Publica. 2013;87(4):407-417. doi:10.4321/S1135-57272013000400010

19. Tenas MJ, Ballesteros A, Barcelo I, et al. Actitud de los profesionales de Atención Primaria frente al tabaco. Semergen. 2008;34(3):113-118. doi:10.1016/s1138-3593(08)71862-8

20. Cerrada EC, Olmeda CL, Senande EB, Rodriguez BG, Sanz CT. Opiniones, prácticas, barreras y predisposición al cambio, a la hora de dar consejo para dejar de fumar (Views, practices, barriers, and the will to change, when counselling to give up smoking is being given). Aten Primaria. 2005;36(8):434-441. doi:10.1157/13081057

21. Fernandez Ruiz ML, Sanchez BM. (Evolution of the prevalence of smoking among female physicians and nurses in the Autonomous Community of Madrid, Spain). Gac Sanit. 2003;17(1):5-10. doi:10.1157/13043417

22. Casas MR, Martin CC, Inglada FM, Roig RL, Moreno CC. Abordaje del tabaquismo entre los trabajadores de un distrito sanitario (Tackling tobacco dependency among a Health District's employees). Aten Primaria. 2002;29(4):218-222. doi:10.1016/s0212-6567(02)70547-7

23. Alonso Gordo JM, Martinez Perez JA, Arribas AJ, Sanchez-Seco HP, Guesta GM, Provencio HR. (Tobacco dependence in primary care: the opinion of professionals in the Guadalajara Health Area). Aten Primaria. 1997;19(8):412-417.

24. Ravara SB, Castelo-Branco M, Aguiar P, Calheiros JM. Smoking behaviour trends among Portuguese physicians: are they role models? A conferencebased survey. Public Health. 2014;128(1):105-109. doi:10.1016/j.puhe.2013.08.015 
25. Ravara SB, Castelo-Branco M, Aguiar P, Calheiros JM. Are physicians aware of their role in tobacco control? A conference-based survey in Portugal. BMC Public Health. 2014;14:979. doi:10.1186/1471-2458-14-979

26. Nobile CG, Bianco A, Biafore AD, Manuti B, Pileggi C, Pavia M. Are primary care physicians prepared to assist patients for smoking cessation? Results of a national Italian cross-sectional web survey. Prev Med. 2014;66:107-112. doi:10.1016/j.ypmed.2014.06.009

27. Sonmez CI, Aydin LY, Turker Y, et al. Comparison of smoking habits, knowledge, attitudes and tobacco control interventions between primary care physicians and nurses. Tob Induc Dis. 2015;13:37. doi:10.1186/s12971-015-0062-7

28. Juranic B, Rakosec Z, Jakab J, et al. Prevalence, habits and personal attitudes towards smoking among health care professionals. J Occup Med Toxicol. 2017;12:20. doi:10.1186/s12995-017-0166-5

29. Azuri J, Nashef S. Primary Care Physicians' Characteristics and Attitudes on Smoking Cessation. Am J Health Behav. 2016;40(5):578-584. doi:10.5993/ajhb.40.5.4

30. Stamatopoulou E, Stamatiou K, Voulioti S, et al. Smoking behavior among nurses in rural Greece. Workplace Health Saf. 2014;62(4):132-134. doi:10.3928/21650799-20140305-05

31. Huddlestone L, Walker GM, Hussain-Mills R, Ratschen E. Treating tobacco dependence in older adults: a survey of primary care clinicians' knowledge, attitudes, and practice. BMC Fam Pract. 2015;16:97. doi:10.1186/s12875-015-0317-7

32. Glahn A, Kyriakos CN, Radu Loghin C, et al. Tobacco control achievements and priority areas in the WHO Europe Region: A review. Tobacco Prevention \& Cessation 2018;4(April 15). doi:10.18332/tpc/89925

33. Joossens L, Raw M. The tobacco control scale 2016 in Europe, 2017. https://www.tobaccocontrolscale.org/. Accessed November 1, 2018.

34. Instituto Nacional de Estadistica: Estadistica de profesionales sanitarios colegiados 2018. http:// www ine es/. Accessed February 27, 2018.

35. Attitudes of Europeans towards tobacco and electronic cigarettes. Special Eurobarometer 458. European Union; 2017.

\section{ACKNOWLEDGEMENTS}

We thank all our colleagues from the Spanish Primary Healthcare Centers for their collaboration in our study.

CONFLICTS OF INTEREST

The authors have completed and submitted the ICMJE Form for Disclosure of Potential Conflicts of Interest and none was reported.

FUNDING

There was no source of funding for this research.

PROVENANCE AND PEER REVIEW

Not commissioned; externally peer reviewed. 